\title{
Lighting and Coloring in Creating Atmosphere of Worship in Church
}

\author{
Tobias Warbung, Nick Soedarso, Rina Carina \\ \{tobias@binus.ac.id ${ }^{1}$, nsoedarso@binus.edu² ,rina.carina@binus.ac.id $\left.{ }^{3}\right\}$ \\ Universitas Bina Nusantara, Jakarta, Indonesia ${ }^{1,2,3}$
}

\begin{abstract}
A Church is considered as a representation of heaven on earth, a symbol of God's presence and a place for celebrating Christian faith where the building must meet the requirements of Christian liturgy. In Christianity, light is considered holy and God himself is light. Light is also one of the important elements in a church that can create the ambiance of worship. It can help people feel closer while they were worshiping God. This research tries to learn about the meaning of light and color in Christian culture and how church using light with its supporting media to produce attractive colors that can build an atmosphere in the process of worshipping God. This research also studies Chartres Cathedral, in Chartres, France, and JPCC, in Jakarta, Indonesia as a case study of using natural light and artificial light to build the atmosphere of worship.
\end{abstract}

Keywords: Church, Light, Color, Christian.

\section{Introduction}

In Christianity light is considered holy and God himself is Light. Meanwhile, a church is a place where Christian people come together to praise and worship God. It is also a place for Christian people can have communities and able to perform activities related to their beliefs. In the past church is considered as a representation of heaven on earth, a symbol of God's presence and a place for celebrating Christian faith. A Church as a building must meet the requirements of Christian liturgy[1]. This is the reason why many churches were built with luxury, using art and using the best materials at the time to represent the presence of God.

If the light is holy, God is light, and the church is the representation of the presence of God, then there is a strong relationship between these three. That is why many churches are using light as one of the tools to create the ambiance. It can help people feel closer while they were worshipping God. In the past, the Church generally used natural light, which is the sunlight that entering through the window. The incoming light can cause certain effects and color that can build an ambiance of worship. Meanwhile, the church nowadays with all their limitations, many of them uses artificial light to build their worship atmosphere.

This research tries to study how the Chartres Cathedral, in Chartres, France, and Jakarta Praise Community Church (JPCC), in Jakarta, Indonesia in using light and color as a tool to build the ambiance by using the existing media so Christian people can enjoy and able to worship God more comfortably. The reason for choosing Chartres Cathedral is because the architecture of the Gothic church is the ultimate proof of the past regarding the use of natural lighting in the realization of the concept of space and stained glass as a medium to build an atmosphere of worship. Meanwhile, JPCC church was chosen because they used artificial light 
produced by the led lamp and Spotlight [2]. The spotlight can be set to produce colors to create a certain mood to create the ambiance of worship.

\section{Research Method}

This research tries to learn about the meaning of light and color in Christian culture and how church using light with its supporting media, so it can produce attractive colors that can build an atmosphere in the process of worshipping God. To learn the impact of light and color in Chartres Cathedral, a collection of literature data is done through journals and books. As for JPCC, color tree by Munsell is used to identify the color produced by artificial light. Research is also carried out by qualitative data collection by observation and interviewing. Observation is done by a direct survey to JPCC church. The interview is done by meeting with Creative Pastors of JPCC church who is responsible for maintaining the Sunday services and lighting expert who has done various lighting project included several churches.

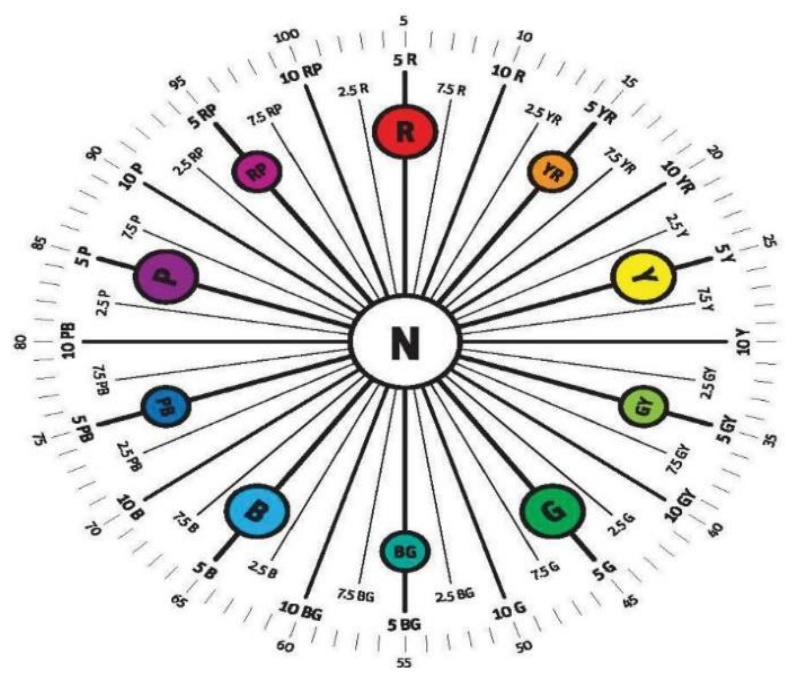

Fig. 1. Musell Color Tree[3]

\section{Result And Discussion}

\subsection{Light in Christian}

Light is an important element for Christian people in worshipping God. According to the Bible, there are several important events marked by the presence of the light, such as the event of Jesus being baptized by John the Baptist and the heaven are opened to celebrate Jesus (Mat3:13-17), the event of Jesus encountering Moses and Elijah on the mountain and the face of Jesus glowing like the sun and His clothing being white and shines like light (Mat17:1-3), or in several occasion when Jesus teaches the crowds and introduces Himself as the Light of the world (John3:19, John8:12, John9:5, John12:46). Because God is light, as a result, light has the divine nature [4]. 


\subsection{Source of light and color}

In general, the source of light is divided into two parts, the natural light that comes from the sun and artificial light that comes from artificial lighting equipment[5]. For natural light, the presence of light in the room aims to illuminate the various forms of elements in the room in such a way that the atmosphere can be perceived visually. To achieve this goal, it requires several things such as design, including processing the shape and position of the light hole, combined with certain materials that are able to reflect or pass on the light.

As for artificial light, although it will not be able to match the perfection of natural light, with the development of technology, artificial light is able to produce the desired color, and allows to make light comes from various angles, such as from the top, left, right, back and bottom to illuminating an object at any time in a space. Various types of irradiation with artificial light are very capable of creating a certain atmosphere that can arouse a person's emotions or feelings. The flexibility of light settings like this is not possible with the use of natural light.

Other things that can affect the atmosphere of the building is the color of light and the reflection produced by the color. Colors have a major effect on moving feelings to create a certain atmosphere and that will happen when there is an interaction between color and light. Color psychology providing something fundamental and very powerful in the experience of human space[2]. Dark colors are often interpreted as sadness, pessimistic, and depressing and bright color interpreted as hope, happiness, and joy[6]. This concept is similar to church when the bright light that comes inside to fill the dark room which represents God's presence and protection to give us joy and happiness in the midst of difficulties.

\subsection{The use of Light and Color in Chartres Catedral}

Gothic style is very thick with vertical elements, the use of stained glass, and the amount of light entering the building[5]. Stained glass has a difference compared to mural or mosaic paintings that decorate the church in the beginning. Stained glass does not reflect light, but is a transmitter, filtering and turning natural light into beautiful colors. Stained glass was first discovered by a monk named Suger when he rebuilt Saint-Denis in 1135. The colors of the light produced by stained glass, later by the monks were called lux nova, "new light". The polychrome rays that enter through the window illuminate the walls and columns, as if overwhelm their feelings. The room filled with light made Suger feel as if he were in an unknown region in the universe that does not exist on the face of the earth or in the purity of Heaven. In Suger eyes, this is a station, the road to heaven, which leads him from an inferior position to a higher world. And in this era, every stained-glass window in the church is considered a holy scripture. After Suger died, stained-glass quickly became the standard in French Gothic architecture including Chartres Cathedral[1]. 


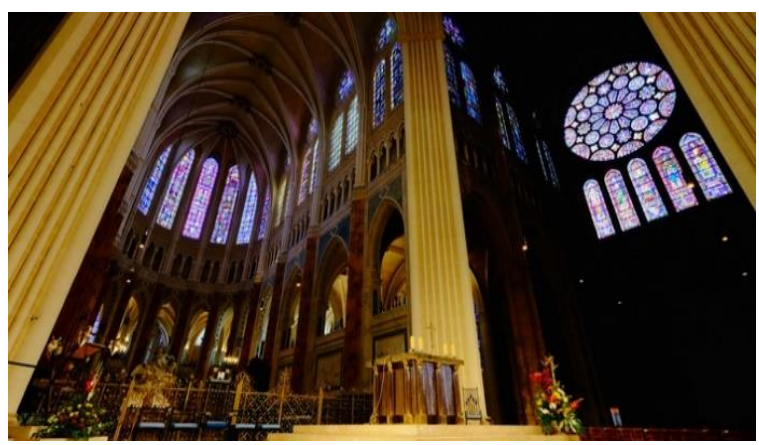

Fig. 2. Chartres Cathedral Stained Glass1

Chartres Cathedral is one of the famous churches building in the Gothic era. In this building, there are 176 windows consisting of various biblical stories from the old agreement to the new agreement (see fig.1). Tree of Jesse, twelve King of Judah and twelve prophets, Apocalypse; Evangelists and prophets, and The Virgin holding the Christ Child are some stories that visitors can enjoy [7]. Stained glass which serves as a tool of entering natural light into the building, can make biblical stories in the church become more divine. With the idea that God is light, the combination of natural light, stories in the stained glass, and the color of the light transmitted into beautiful colors make the presence of God more and more felt by the congregation who come to the church. The light that enters the church also represents the light that comes from darkness.

\subsection{Worship and Liturgy in Christian}

True worship in the Bible speaks about our daily lives, how we live a life that is pleasing to God (Rom. 12: 1). But in the context of church liturgy, worship is often associated with songs sung during worship.

For the liturgy, every church has different ways of worship. Although different, we can draw a number of similarities, including singing and learning the Word of God (sermon). For the purposes of this study, the liturgy used is singing and preaching.

\subsection{The use of Light and Color in JPCC Church}

The church today still has the same function of places to worship. But as more and more Christians grow, more churches are needed. With its limited resources and various reasons, several churches choose a building or rent a multipurpose room in the mall as their place to worship God.

Jakarta Praise Community Church (JPCC) is a church that has 2 locations located on 3-4 floors in Mall Kota Kasablanka, and the other one is located at Annex Building 10-12 floors, Sudirman, Jakarta. Every week on average there are about 18,000 - 20,000 Christian people worshipping at JPCC, and a total of 7 services in Kota Kasablanka and Annex building are held to accommodate the congregation. According to the Creative Pastor, JPCC is very focused on the comfort of the congregation when they are worshiping. One of them is by using LED lights and spotlights[8].

\footnotetext{
${ }^{1} \mathrm{http} / / /$ chartrescathedral.net/chartres-cathedral-stained-glass/
} 


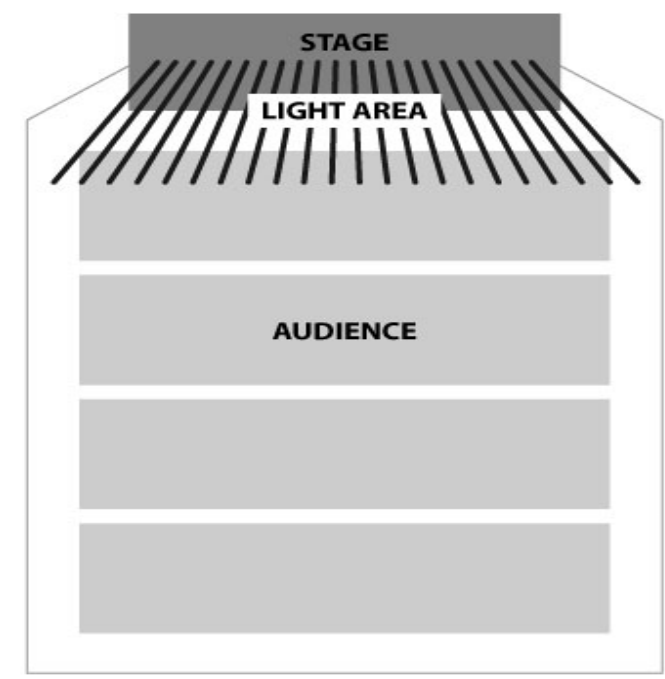

Fig. 3. Illustration of the lighting area in the hall

At JPCC, there is two type of songs: praise songs and worship songs. In this part, the room light is dimmed, then spotlight LED are used to illuminate the stage with colors that are set to make the stage the center of attention. The spotlight area is set only to illuminate the stage until the front area of the audience (see fig. 3) so that the audience can be more intimate and focused on singing and praying with the help of the color produced and not to worry their eyes will be hit directly by spotlight [9].

For fast tempo praise songs, the atmosphere made to be more active with the spotlight is set using a three-color combination where two colors are spaced equally and accompanied by a single-color opposite in a color circle to produce contrast colors (Split complementary) such as blue, purple, and yellow (see fig. 4). Just like complimentary colors, this color combination can create visual vibrate that excites the eye [6], so that the congregation can influence the congregation to sing with more joy and enthusiasm.

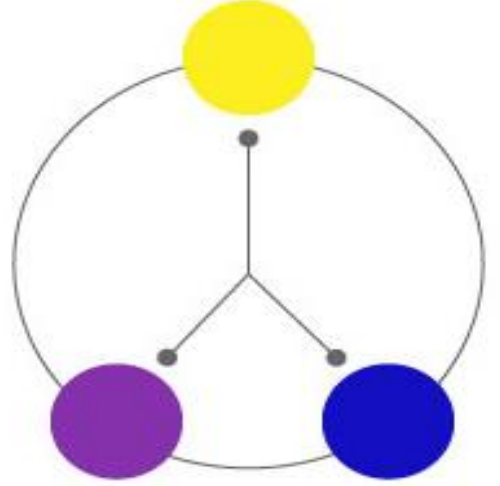

Fig. 4. Split complementary Color 


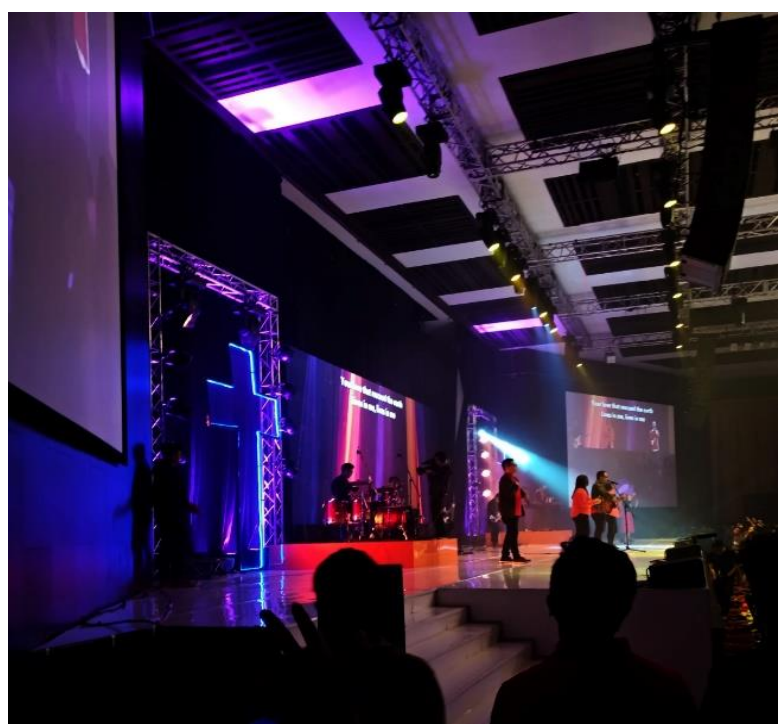

Fig. 5. JPCC Church while singing a praise song

For worship songs with a slower tempo, the atmosphere is made to be more intimate and dramatic. Spotlight lights are set using two or more color combinations that are close together in a color circle (analogous color) such as red-purple, red, red-orange, and orange (see fig.6). These colors are a color combination that is easily accepted with the eye[6] so that it can help the congregation to sing more intently and intimately.

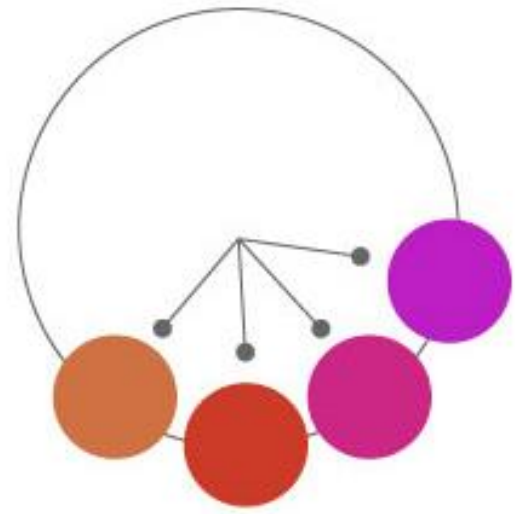

Fig. 6. JPCC Analogous Color

For sermons, spotlight lights are made in standby mode and the room is made into a yellowish color with LED lights. This is made so that the congregation can focus on the speaker who teaches the Word of God on the stage. And the yellowish color makes the congregation more comfortable in listening to the Word of God.

Although artificial light may look like loses its divine nature compared to natural light, artificial light is still able to help the congregation focus on worshiping God. This can be seen from the number of congregations come consistently every week. 


\section{Conclusion}

In Christianity, light is considered holy and light is God Himself. At Chartres Cathedral, by using stained glass, the natural light is transmitted into beautiful colors that make the church atmosphere more divine. Supported by biblical stories in the windows, and the color of the light that represents the light that comes from darkness made the presence of God felt more real. In contrast to JPCC church, they use artificial light with media such as led lights and spotlight to build their worship atmosphere. The lights are set to produce colors to create the mood that suits their liturgy, so the congregation can worship more comfortably and focus on God.

From this research, it can be learned that light, whether it is natural light or artificial light, if used properly can build an atmosphere of worship in the church. Especially if used with supporting media such as stained glass or spotlight, can produce attractive colors that affect people who see it. Artificial light in the context of the church despite losing its divine nature, can still be used to build an atmosphere of worship with different approaches. Artificial light is also very flexible because, with its technological advances, they can achieve things that cannot be achieved by natural light. But even though natural light is limited, in the context of the church still has divine nature and reflect better when the light enters the church.

\section{References}

[1] F. Kleiner, Gardner's Art through the Ages: A Concise Global History. Massachusetts: Clark Baxter, 2009.

[2] N. Akhtar, S. A. and M. Salman, Asad-Ur-Rehman, and A. Ijaz, "Interior Design and its Impact on of Employees' Productivity in Telecom Sector, Pakistan," J. Asian Bus. Strateg., pp. 74, 82, 2014.

[3] T. Morioka, A. Stone, Color Design Workbook-A Real-World Guide to Using Color in Graphic Design. USA: Rockport Publisher, 2006.

[4] S. Honggowidjaja, "No TiPengaruh Signifikan Tata Cahaya pada Desain Interior," p. 5, 2013.

[5] H. G. B. Setiawan, "Pencahayaan Buatan Pada Pendekatan Teknis dan Estetis Untuk Bangunan dan Ruang Dalam," vol. HUMANIORA, pp. 1224-1225, 2014.

[6] M. Babolhavaeji, "The Role of Product Color In Consumer Behaviour, Advanced Social Humanities, and Management," Adv. Soc. Humanity. Manag., vol. Vol.2, pp. 9-15, 2015.

[7] Chartrescathedral.net, "Chartres Cathedral Stained Glass," 2018.

[8] K. Goh, The Impact of Design and Lighting to Create an Atmosphere of Worship in Church. Jakarta, 2018.

[9] R. Rumuy, Stage Lighting in Church, Binus University. Jakarta, 2018. 